\title{
Association of HLA class II genes with susceptibility to Crohn's disease
}

\author{
P-M Danzé, J-F Colombel, S Jacquot, M-N Loste, D Heresbach, S Ategbo, S Khamassi, \\ B Périchon, G Semana, D Charron, J-P Cézard
}

Laboratoire de Lochimie, Hôpital B Services d'HépatoGastroentérologie et de Pédiatrie, Hôpital Huriez, CH et U Lille, France

P-M Danzé

J-F Colombel

$S$ Ategbo

S Khamassi

Service d'Hépato-

Gastroentérologie et

Laboratoire

d'Immunologie et

d'Histocompatibilité,

Hôpital St-Louis,

Paris, France

$S$ Jacquot

M-N Loste

D Charron

Service d'Hépato-

Gastroentérologie,

CHRU Pontchaillou et

Laboratoire

d'Histocompatibilité,

CRTS Rennes, France

D Heresbach

G Semana

Inserm U120 et Service de Gastroentérologie et Nutrition

Pédiatrique, Hôpital R

Debré, Paris, France

B Périchon

J-P Cézard

Correspondence to:

Dr J F Colombel, Clinique

des maladies de l'Appareil

Ds maladies de 1 Appareil

Hôpital Huriez, CHRU Lille,

59037, Lille, France.

Accepted for publication

30 January 1996

\begin{abstract}
Background-Published studies on the association between HLA class II genes and inflammatory bowel disease are contradictory perhaps because of the limited size and ethnic heterogeneity of the populations studied.

Aim-To compare the frequencies of HLA class II genes in a large number of French patients with Crohn's disease and in an ethnically matched control group.

Methods-344 patients (196 F, 148 M, mean age 23.6 years) with Crohn's disease were molecularly genotyped for the HLADQB1 and DRB1 alleles. The results were compared with those for an ethnically matched control population of 488 white adults.

Results-There were two significant variations of alleles at the DQB1 locus: an increase in $\mathrm{DQB1}{ }^{\star} 0501$ allele frequency $\left(\chi^{2}=10 \cdot 6\right.$, corrected $p$ value $(p c)=0.01$, odds ratio $(O R)=1.61$ ) and a decrease in DQB1*0602/0603 allele frequencies $\left(\chi^{2}=8.43, \quad\right.$ pc $=0.037, \quad$ OR $\left.=0.66\right) . \quad$ DRB1 analysis showed associations with three allelic variations: an increase in the frequencies of DRB1 $\star 01\left(\chi^{2}=12 \cdot 86, \mathrm{pc}=0 \cdot 003\right.$, $O R=1 \cdot 75)$ and $D R B 1 * 07$ alleles $\left(\chi^{2}=11 \cdot 18\right.$, $\mathrm{pc}=0.008, \mathrm{OR}=1 \cdot 58)$ and a very significant decrease in that of the DRB1*03 allele $\left(\chi^{2}=19 \cdot 7, \mathrm{pc}=9 \cdot 10^{-5}, \mathrm{OR}=0 \cdot 46\right)$.

Conclusion-The alleles DRB1*01 and DRB1*07 are associated with susceptibility to Crohn's disease. The strong negative association between the DRB1*03 allele and Crohn's disease suggests that the HLA-DRB1*03 allele mediates 'resistance' to Crohn's disease.

(Gut 1996; 39: 69-72)
\end{abstract}

Keywords: Crohn's disease, disease association, HLA class II genes.

Inflammatory bowel diseases (IBD) are complex, multifactorial diseases partly determined by genetic predisposition. ${ }^{1}$ Particular attention has been paid to genes related to immune function, as the prevailing view is that an immunological process participates in IBD. ${ }^{1} \mathrm{~A}$ linkage analysis of chromosome 6 loci in familial aggregations of Crohn's disease (CD) showed neither individual nor combined lod scores for any family or any locus high enough to suggest linkage or genetic heterogeneity. ${ }^{2}$ However, this finding does not exclude the possibility that HLA genes might modulate the expression of the disease. Studies of the association of IBD with HLA class II genes may still be important because HLA genes restrict antigen recognition, control the immune response, and are associated with autoimmune disorders. Most association studies carried out so far have used serological techniques. Seven studies have shown an increase in the frequency of HLA-DR2 in ulcerative colitis (UC), although only two reached statistical significance. ${ }^{13}$ Results in $\mathrm{CD}$ are even more controversial. Japanese workers found a positive association between DR4 antigen and CD, ${ }^{4}$ whereas Smolen $e t a l^{5}$ reported a slight increase in HLA-DR7 antigen. The difference in HLA-DR7 antigen between $\mathrm{CD}$ and UC was highly significant. These conflicting results may result from the limited size and ethnical heterogeneity of the populations studied and the use of serological techniques, which did not discriminate well enough between HLA class II specificities. Few studies have examined the role of HLA genes as immunogenetic markers of IBD using novel genotyping procedures. Recently, Toyoda et $a^{6}$ described a positive association of UC with DR2 alleles and of CD with the combination of DR1 and DQ5 alleles in a Californian population. But other reports have failed to confirm these associations in European populations. ${ }^{78}$

This report describes the analysis of HLA class II genes in a large number of French patients; there were positive associations between $\mathrm{CD}$ and $\mathrm{DRB} 1^{\star} 01$ and $\mathrm{DRB1}{ }^{\star} 07$ alleles and a strong negative association between $C D$ and DRB $1{ }^{\star} 03$ alleles.

\section{Methods}

Crohn's disease

A total of 344 unrelated white patients with CD were studied (196 women and 148 men, mean age 23.6 years, range 3-74). CD was diagnosed using previously described criteria. ${ }^{9}$ All patients were from the north of France (48\%, 135 adults, 30 children), Paris region $(30 \%, 56$ adults, 46 children) or Brittany (22\%, 67 adults, 10 children).

\section{Control population}

Healthy white subjects were selected at random from each region and their HLA DQB1 and DRB1 alleles were genotyped. In all, 488 subjects were analysed (44\% from the north of France, $38 \%$ from Brittany, and $18 \%$ from Paris). The control results were pooled, as no significant differences in allele 
TABLE I Frequencies of HLA-DQB1 alleles in patients with Crohn's disease (CD) and in controls

\begin{tabular}{|c|c|c|c|c|c|c|c|}
\hline \multirow[b]{2}{*}{$D Q B 1^{*}$ allele } & \multicolumn{2}{|c|}{$\begin{array}{l}\text { Control group } \\
(n=976)\end{array}$} & \multicolumn{2}{|c|}{$\begin{array}{l}C D \text { patients } \\
(n=686)^{\star}\end{array}$} & \multicolumn{3}{|c|}{$C D$ versus controls } \\
\hline & $n$ & $\%$ & $n$ & $\%$ & $p c$ & $x^{2}$ & $O R(C I)$ \\
\hline 0201 & 205 & $21 \cdot 00$ & 140 & $20 \cdot 41$ & NS & & \\
\hline 0301 & 192 & $19 \cdot 67$ & 157 & $22 \cdot 89$ & NS & & \\
\hline 0302 & 100 & $10 \cdot 25$ & 53 & $7 \cdot 73$ & NS & & \\
\hline 0303 & 44 & 4.51 & 30 & $4 \cdot 37$ & NS & & \\
\hline $0304 / 0305$ & 3 & 0.31 & 2 & $0 \cdot 29$ & NS & & \\
\hline $0401 / 0402$ & 27 & $2 \cdot 77$ & 17 & $2 \cdot 48$ & NS & & \\
\hline 0501 & 100 & $10 \cdot 25$ & 107 & 15.60 & 0.01 & $10 \cdot 6$ & $1.61(1.21$ to $2 \cdot 17)$ \\
\hline 0502 & 19 & 1.95 & 9 & 1.31 & NS & & \\
\hline 0503 & 42 & $4 \cdot 30$ & 26 & 3.79 & NS & & \\
\hline 0601 & 10 & $1 \cdot 02$ & 6 & 0.87 & NS & & \\
\hline $0602 / 0603$ & 185 & 18.95 & 93 & $13 \cdot 56$ & 0.037 & $8 \cdot 43$ & $0.66(0.51$ to 0.88$)$ \\
\hline $0604 / 0605$ & 49 & $5 \cdot 02$ & 46 & $6 \cdot 70$ & NS & & \\
\hline
\end{tabular}

$\mathrm{n}$ : Number of alleles; pc: p corrected values; OR: odds ratio; (CI): confidence interval; ${ }^{\star}: 1$ of 344 patients was not genotyped.

TABLE II Frequencies of HLA-DRB1 alleles in patients with Crohn's disease (CD) and in controls

\begin{tabular}{|c|c|c|c|c|c|c|c|}
\hline \multirow[b]{2}{*}{$D R B 1$ * allele } & \multicolumn{2}{|c|}{$\begin{array}{l}\text { Control group } \\
(n=976)\end{array}$} & \multicolumn{2}{|c|}{$\begin{array}{l}C D \text { patients } \\
(n=688)\end{array}$} & \multicolumn{3}{|c|}{$C D$ versus controls } \\
\hline & $n$ & $\%$ & $n$ & $\%$ & $p c$ & $x^{2}$ & $O R(C I)$ \\
\hline $\begin{array}{l}01 \\
15 / 16 \\
03 \\
04 \\
11 / 12 \\
13 / 14 \\
07 \\
08 \\
09 \\
10\end{array}$ & $\begin{array}{r}88 \\
135 \\
130 \\
165 \\
129 \\
175 \\
109 \\
27 \\
9 \\
9\end{array}$ & $\begin{array}{r}9.02 \\
13.83 \\
13.32 \\
16.91 \\
13.22 \\
17.93 \\
11.17 \\
2.77 \\
0.92 \\
0.92\end{array}$ & $\begin{array}{r}101 \\
77 \\
45 \\
105 \\
97 \\
117 \\
116 \\
19 \\
4 \\
7\end{array}$ & $\begin{array}{r}14 \cdot 68 \\
11 \cdot 19 \\
6 \cdot 54 \\
15 \cdot 26 \\
14 \cdot 10 \\
17 \cdot 01 \\
16 \cdot 86 \\
2.76 \\
0.58 \\
1.02\end{array}$ & $\begin{array}{l}0 \cdot 003 \\
\text { NS } \\
9 \cdot 10^{-5} \\
\text { NS } \\
\text { NS } \\
\text { NS } \\
0 \cdot 008 \\
\text { NS } \\
\text { NS } \\
\text { NS }\end{array}$ & $\begin{array}{l}12 \cdot 86 \\
19 \cdot 7\end{array}$ & $\begin{array}{l}1.75(1.28 \text { to } 2.35) \\
0.46(0.31 \text { to } 0.65)\end{array}$ \\
\hline
\end{tabular}

Abbreviations as in Table I.

frequencies between the three regions were observed.

\section{HLA class II genotyping}

DNA was extracted from fresh or frozen peripheral blood leucocytes by standard techniques; genomic DNA was isolated by phenol-chloroform extraction of dodecylsulphate-lysed and proteinase $\mathrm{K}$ treated cells. The second exon encoding the polymorphic outer domains of HLA DR $\beta$ and DQ $\beta$ chains was amplified separately by a polymerase chain reaction (PCR) procedure using specific flanking primers. ${ }^{10}$ The DRB1 exon 2 was amplified using a procedure initially described by Yunis et $a l^{11}$ and called amplification fragment length polymorphism (AFLP). ${ }^{12} \mathrm{Six}$ group specific sense primers and one antisense primer were used for the amplification of HLA-DRB1 alleles. DQB1 alleles were also typed using appropriate primers. ${ }^{13}$ The results obtained with this technique and other molecular methods are in good agreement. ${ }^{14} 15$

After amplification, $10 \mu$ l of PCR products were taken for each digestion reaction. Different panels of restriction endonucleases were used according to the locus studied. Digested DNA samples were then run on an $8 \% \mathrm{w} / \mathrm{v}$ polyacrylamide vertical electrophoresis gel $(200 \mathrm{~V}, 300 \mathrm{~mA})$ and fragments were visualised by staining with ethidium bromide. Restriction endonuclease mapping of the PCR products provided a simple and precise way of defining HLA class II alleles at the nucleotide level. The nomenclature for factors of the HLA system 1994 was used throughout. ${ }^{16}$
Statistical analysis

The statistical significance of differences in allele frequencies between patients and controls was measured by the $\chi^{2}$ test with Yates's correction. The level of significance was $p<0.05$. For allelic comparisons, $p$ values were corrected $(\mathrm{pc})$ for the number of comparisons according to Svejgaard et al. ${ }^{17}$ For correlations between HLA alleles and clinical sub-groups, $p$ values were corrected for the number of alleles studied and by the number of different sub-groups.

\section{Results}

Frequency of HLA alleles

Tables I and II give the comparisons of allele frequencies in CD patients and controls. The corrected $\mathrm{p}$ values indicated two significant variations in the DQB1 locus: an increase in $\mathrm{DQB} 1{ }^{\star} 0501$ allele frequency $\left(\chi^{2}=10 \cdot 6, \mathrm{pc}=\right.$ 0.01 , odds ratio $(O R)=1.61)$, and a decrease in the frequencies of the DQB1*0602/0603 alleles $\left(\chi^{2}=8.43, \quad \mathrm{pc}=0.037, \quad \mathrm{OR}=0.66\right)$. DRB1 analysis showed associations with three allelic variations: an increase in the frequencies of HLA-DRB ${ }^{\star} 01 \quad\left(\chi^{2}=12 \cdot 86, \quad \mathrm{pc}=0.003\right.$, $\mathrm{OR}=1 \cdot 75)$ and HLA-DRB1 ${ }^{\star} 07$ alleles $\left(\chi^{2}=\right.$ $11.18, \mathrm{pc}=0.008, \mathrm{OR}=1.58)$ and a very significant decrease in that of the HLA$\mathrm{DRB}^{\star}{ }^{\star} 03$ allele $\left(\chi^{2}=19 \cdot 7, \mathrm{pc}=9 \cdot 10^{-5}, \mathrm{OR}=\right.$ $0 \cdot 46)$.

\section{$H L A-D R B 1-D Q B 1$ allele combinations}

DRB1-DQB1 haplotypes were assigned on the basis of two locus associations and known linkage disequilibria, as described in the 11th International Histocompatibility Workshop. ${ }^{18}$ HLA-DRB ${ }^{\star} 01$ alleles are in strong linkage disequilibrium with the $\mathrm{DQB}{ }^{\star}{ }^{*} 0501$ allele in white populations. The combination $\mathrm{DRB} 1{ }^{\star} 01-\mathrm{DQB} 1{ }^{\star} 0501$ was overexpressed in the $C D$ population, but neither the $p$ value nor OR were greater than those for $\mathrm{DRB} 1^{\star} 01$ or DQB1*0501 alone (data not shown).

$\mathrm{DRB}^{\star}{ }^{\star} 1301, \mathrm{DRB} 1^{\star} 1302$, and DRB1*1401 were in linkage disequilibrium with $\mathrm{DQB} 1^{\star}$ 0603, DQB1*0604, and DQB1*05031 respectively. The most important alleles in $\mathrm{DRB} 1^{\star} 02$ are $\mathrm{DRB} 1^{\star} 1501$ and $\mathrm{DRB1}{ }^{\star} 1601$, which were in linkage disequilibrium with DQB1*0602 and DQB1*0502 respectively in the French population (data not shown). As the frequencies of these two DRB1 alleles were not changed in $C D$, the significant decrease in the frequencies of the DQB ${ }^{\star} 0602$ and ${ }^{\star} 0603$ alleles seems to be allelic.

No haplotypic effect was observed for $D R B 1{ }^{\star} 03$ or $\mathrm{DRB} 1{ }^{\star} 07$ alleles.

\section{HLA alleles and clinical features}

On sub-group analysis no association between allelic frequency, and groups defined by sex, age at diagnosis, disease location, disease type, ${ }^{19}$ previous surgery, and the use of immunosuppressive was found. 


\section{Discussion}

Using HLA genotyping procedures, we showed an overall positive association between $\mathrm{CD}$ and $\mathrm{DRB} 1^{\star} 01$ and $\mathrm{DRB} 1^{\star} 07$ alleles and $\mathrm{a}$ negative association between $C D$ and the DRB $1{ }^{\star} 03$ allele. These results are probably relevant because we studied a large population taken from three different regions of France, and obtained homogeneous results in both the patient group and controls. Furthermore, the statistical testing of allele distribution was done with correction for the number of antigens tested, which makes the results more powerful.

HLA-DRB $1^{\star} 03$ is positively associated with several diseases, including type I diabetes, primary sclerosing cholangitis, and coeliac disease. ${ }^{2021}$ Conversely, the most impressive result that we observed in this study was an important decrease in HLA-DRB1 03 in CD. The estimated strength of the negative association between carrying these alleles and CD was OR50.46. This variation has also been described in a preliminary report from Germany. ${ }^{8}$ It might even be a wider characteristic of IBD, as we have also observed a negative association with $\mathrm{DRB}^{\star} 03$ in patients with UC. ${ }^{22}$ If confirmed, this suggests that HLA-DRB $1{ }^{\star} 03$ alleles mediate 'resistance' to IBD. Such an effect has been proposed for insulin dependent diabetes mellitus and DRB1 ${ }^{\star} 15$, DRB1* $11^{23}$ The mechanisms underlying this protective effect of $\mathrm{DRB} 1{ }^{\star} 03$ in $C D$ are still speculative and require further study.

The increases in $\mathrm{DRB} 1^{\star} 01$ allele (that is, DRB1 ${ }^{\star} 0101,{ }^{\star} 0102$ or ${ }^{\star} 0103$ ) frequencies in CD in our study is in accordance with the findings of Toyoda $e t a l,{ }^{6}$ but with a lower $p$ value $(0.003)$. The $p$ value of Toyoda et al $(0.026)$ was not corrected for the number of alleles tested. However, Toyoda et al found a more significant association of the haplotype DRB1*01-DQB1*05 (DQB1*0501 allele usually associated with $\mathrm{DRB} 1^{\star} 01$ ), than of $D R B 1{ }^{\star} 01$ alleles alone, which suggested that DRB1 itself was not the primary locus for the association. No association of $\mathrm{CD}$ with $\mathrm{DRB}^{\star}{ }^{\star} 01$ alleles was shown in two European studies, performed in Germany (81 patients) ${ }^{8}$ and Sweden (118 patients). ${ }^{7}$ The relevance of DRB $1^{\star} 01$ as an important genetical marker thus remains open.

Smolen et $a l^{5}$ used serological methods to show an increase in DR7 serotype in CD, but they examined very few patients $(n=27)$ and the difference reached significance only when compared with UC. More recently, Boehm et $a l^{8}$ used methods similar to ours and found an association between the HLA-DRB ${ }^{\star} 07$ allele and CD in 81 patients from Germany. The DRB1*07 allele was also associated with psoriasis, ${ }^{24}$ and the concurrence of psoriasis and $C D$ in both subjects and families has been described. 2526 Our findings might reinforce the possibility of a genetic link between the two disorders. Finally, it is perhaps significant that a viral cause for $C D$ has been proposed ${ }^{27}$ and DR7 has recently been shown to be associated with persistent viral infection. ${ }^{28}$
The differing results and the lack of a definite association between CD and HLA could be partly due to disease heterogeneity. ${ }^{13}$ There is some evidence that genes in the HLA region may influence the severity of IBD. In UC, the HLA-DRB1*1502 allele has been associated with pancolitis with intractable disease $^{29}$ and with corticosteroid treatment. ${ }^{30}$ However, in our study, using $p$ corrected values for the number of alleles studied and for the number of different sub-groups, no significant association was observed between HLA alleles and clinical data.

In conclusion, in linkage analysis studies using the parametric lod score method ${ }^{4}$ and, more recently, a non-parametric two point sibpair linkage method, ${ }^{31}$ we found that HLA genes do not include the major genes for familial CD. However, this report and other association studies ${ }^{6-8}$ suggest that HLA genes have a significant but probably minor contribution in the expression of the disease.

This work was supported by The Fonds de Recherche de la Société Nationale Française d'Hépato-Gastroentérologie, the
Ministère des Affaires Sociales et de la Santé, PHRC: Ministère des Affaires Sociales et de la Santé, PHRC:
AOA94012P950412 and the Comité Directeur HospitaloAOA94012P950412 and the Comité Directeur Hospitalo93-11).

1 Yang H, Rotter IL. Genetics of inflammatory bowel disease. In: Targan SR, Shanahan $\mathbf{F}$, eds. Inflammatory bowel In: Targan SR, Shanahan F, eds. Inflammatory bowel Wilkins, 1994: 32-64.

2 Hugot JP, Laurent-Puig P, Gower-Rousseau C, CaillatZucman S, Beaugerie $\mathrm{L}$, Dupas $\mathrm{JL}$, et al. Linkage analysis of chromosome 6 loci, including HLA, in familial aggregations of Crohn's disease. Am $\mathcal{F}$ Med Genet 1994; 52: 207-13.

3 Satsangi J, Jewell DP, Rosenberg WMC, Bell JI. Genetics of inflammatory bowel disease. Gut 1994; 35: 696-700.

4 Fujita K, Naito S, Okabe N, Yao T. Immunological studies in Crohn's disease. I. Association with HLA systems in the Japanese. F Clin Lab Immunol 1984; 14: 99-102.

5 Smolen JS, Gangl A, Polteraeur P, Menzel EJ, Mayr WR. HLA antigens in inflammatory bowel disease. GLA antroenterology 1982; 82: 34-8.

6 Toyoda H, Wang SJ, Yang HY, Redford A, Magalong D, Tyan D, et al. Distinct association of HLA class II genes with inflammatory bowel disease. Gastroenterology 1993; 104: 741-8.

7 Wassmuth R, Keller Y, Thomson G, Starch M, Lindhagen $\mathrm{T}, \mathrm{Holmberg} \mathrm{E}$, et al. HLA DPB1 alleles provide protection against Crohn's disease in Caucasians. Eur $\mathfrak{F}$ Gastroenterol Hepatol 1994; 6: 405-11.

8 Boehm BO, Reinshagen M, Loeliger C, Kuehnl P, Adler G. HLA class II genes in Crohn's disease: a population based analysis. Gastroenterology 1994; 106: 654A.

9 Gower-Rousseau C, Salomez JL, Dupas JL, Marti R, Nuttens MC, Votte A, et al. Incidence of inflammatory bowel disease in northern France (1988-1990). Gut 1994; 35: 1433-8.

10 Saiki RK, Gelfand DH, Stoffel S, Scharf SJ, Higuchi R, Horn GT, et al. Primer-directed enzymatic amplification of DNA with thermostable DNA polymerase. Science 1988; 239: 487-91.

11 Yunis I, Salazar M, Yunis EJ. HLA DR genetic typing by AFLP. Tissue Antigens 1991; 38: 78-88.

12 Danzé PM, Bianchi F, Fajardy I, Rousseaux J. An improved strategy for HLA-DRB1 subtyping by digestion of PCRamplified DNA with allele-specific restriction endonucleases. Electrophoresis 1995; 5: 7-13.

13. Gu XF, Elion J, Ouagued $M$, Clauser E, Assan R, Krishnamoorthy $\mathbf{R}$. A simple strategy to specifically amplify the HLA-DQ $\beta$ gene region with genomic DNA as amplify the HLA-DQ 3 gene region with

14 Mizuki N, Ohno S, Sugimura K, Seki T, Kikuti YY, Ando A, et al. PCR-RFLP is as sensitive and reliable as PCRSSO in HLA class II genotyping. Tissue Antigens 1992; 40: 100-3.

15 Thonnard J, Deldime F, Heusterspruete M, Delepaut B, Hanon F, De Bruyère M, et al. HLA class II genotyping: two assay systems compared. Clin Chem 1995; 41: 553-6.

16 Bodmer JG, Marsh SGE, Albert ED, Bodmer WF, Dupon B, Erlich HA, et al. Nomenclature for factors of the HLA system, 1994. Tissue Antigens 1994; 44: 1-18.

17 Svejgaard A, Jersild C, Nielsen LS, Bodmer WF. HLA antigen and disease: statistical and genetic considerations. Tissue Antigens 1974; 4: 95.

18 Imanishi $T$, Akaza T, Kimura A, Tokunaga $\mathrm{K}$, Gojobori $T$. Allele and haplotype frequencies for HLA and complement loci in various ethnic groups. In: Tsuji $K$, Aizawa $M$, 
Sasazuki T, eds. HLA 1991. Proceeding of the eleventh international histocompatibility workshop and conference. Oxford: Oxford Sci, 1992; 1: 1118-26.

19 Sachar DB, Andrews H, Farmer RG, Pallone F, Pena AS, Prantera $\mathrm{C}$, et al. Proposed classification of patient subgroups in Crohn's disease. Working team report 4. Groups in Crohn's disease. Wterol Int 1992; 3: 141-5.

20 Charron D. Molecular basis of human leukocyte antigen class II disease associations. Adv Immunol 1990; 48: 107-58.

21 Manns MP, Krüger M. Immunogenetics of chronic liver disease. Gastroenterology 1994; 106: 1676-97.

22 Heresbach D, Colombel JP, Danzé PM, Semana G. The HLA ORB $1^{\star} 0301$ haplotype confers protection against inflammatory bowel disease. $A m \mathcal{F}$ Gastroenterol (in press).

23 Nepom GT. A unified hypothesis for the complex genetics of HLA association with IDDM. Diabetes 1990; 39: 1153-7.

24 Schmitt-Egelnolf $M$, Boehncke WH, Ständer M, Eiermann TH, Sterry W. Oligonucleotide typing reveals association of type I psoriasis with the HLA-DRB1*0701/2, DQA1*0202, DQB1*0303 extended haplotype. Dermatol 1993; 100: 749-52.
25 Hughes S, Wiliams SE, Turnberg LA. Crohn's disease and psoriasis. N Engl f Med 1983; 308: 101

26 Lee FI, Bellary SV, Francis C. Increased occurrence of psoriasis in patients with Crohn's disease and their relatives. Am f Gastroenterol 1990; 85: 962-3.

27 Wakefield EJ, Pittilo RM, Sim R, Cosby SL, Stephenson $J R$, Dhillon AP, et al. Evidence of persistent measles virus infection in Crohn's disease. $\mathcal{F}$ Med Virol 1993; 39: 28 345-53. Almarri A, Batchelor JR. HLA and hepatitis B infection.
Lancet 1994; 344: 1194-5.

29 Masuda H, Nakamura Y, Tanaka T, Hayakawa S. Distinct relationship between HLA-DR genes and intractability of ulcerative colitis. Am f Gastroenterol 1994; 89: 1957-62. 30 Futami S, Aoyama N, Honsako Y, Tamura T, Morimoto S, Nakashima T, et al. HLA-DRB1*1502 allele, subtype of DR15 is associated with susceptibility to ulcerative colitis and its progression. Dig Dis Sci 1995; 40: 814-8.

31 Hugot JP, Laurent-Puig P, Gower-Rousseau C, Olson JM, Lee JC, Beaugerie L, et al. Mapping of a susceptibility locus for Crohn's disease on chromosome 16. Nature 1996; 379: 821-3. 